https://doi.org/10.15407/dopovidi2020.01.089

УДК 577.32:577.112

\title{
О.Ю. Скоробогатов,
}

\section{І.Ю. Жуков, 3.Ю. Ткачук}

Інститут молекулярної біології і генетики НАН України, Київ

E-mail: skorobogatov.alx@gmail.com

\section{Структурні механізми взаємодії дефосфорильованих 2'-5' -триаденілатів з білком S100A1}

\author{
Представлено академіком НАН України М.А. Тукалом
}

За допомогою методів ЯМР спектроскопії та комп'ютерного моделювання вивчали структурні механізми взаємодії дефосфорильованих 2'-5'-триаденілатів з білком S100A1. Встановлено, що дефосфорильований 2' 5'-триаденілат зв'язується з білком S100A1 на межі Са ${ }^{2+}$-зв'язувального домену та лінкерного регіону. Утворення комплексу білок-триаденілат стабілізується трьома зв'язками, два з яких електростатичні, а один водневий. Зафіксовані особливості взаємодіі дефосфорильованого 2'-5'-триаденілату з S100A1 можуть бути підгрунтям для пояснення однієї з неописаних раніше функиій дефосфорильованого 2'-5'-триаденілату.

Ключові слова: дефосфорильовані 2'-5'-триаденілати, білок S100A1, комп'ютерне моделювання, ЯМР.

На сьогодні відомо, що олігоаденілати відіграють ключову роль у так званому олігоаденілатному шляху активації інтерферону, механізм якого полягає в активації останнім ферменту 2'-5'-олігоаденілатсинтетази. Фермент, у свою чергу, використовує внутрішньоклітинний пул АТФ для синтезу особливого класу сполук $-2^{\prime}-5^{\prime}$-олігоА ${ }_{n}$, де $n=2 \div 6$, серед яких кількісно переважають тричленні сполуки. У подальшому олігоА $\mathrm{A}_{n}$ активують латентну РНКазу L, що здатна гідролізувати вірусні та матричні РНК [1].

Крім того, клітинний пул 2'-5'-олігоА лати, які утворюються в результаті ензиматичного відщеплення фосфатних груп. Біологічна роль дефосфорильованих оліго $\mathrm{A}_{n}$ на сьогодні залишається незрозумілою.

Раніше було виявлено, що природний $2^{\prime}-5^{\prime}-\mathrm{A}_{3}$ та його епоксимодифікований аналог 2'-5'- A $_{3}$-еро здатні впливати на процес скорочення препаратів судин гладеньких м'язів in vivo [2]. Таку активність можна пояснити декількома шляхами, одним з яких є можлива взаємодія олігоаденілатів з білками, що беруть участь у м'язовому скороченні, зокрема кальмодуліну та S100A1, i, як наслідок, модуляція їх активності певним чином. I справді, можливість утворення комплексу 2'-5'- $\mathrm{A}_{3}-\mathrm{CaM}$ in vitro вже було показано раніше [3]. Виявилося,

(C) О.Ю. Скоробогатов, І.Ю. Жуков, 3.Ю. Ткачук, 2020 
що зв’язування олігоаденілату з кальмодуліном спричиняє зміни афінності білка до Са ${ }^{2+}$. На підставі цих даних можна припустити, що олігоаденілати здатні зв’язуватися і з іншим ключовим $\mathrm{Ca}^{2+}$-зв'язувальним білком - S100A1, який є антагоністом кальмодуліну з точки зору впливу на ріанодиновий рецептор [4]. 3 цієї причини вивчення особливостей зв'язування S100A1 з 2'-5'- A $_{3}$ було одним з головних завдань даного дослідження.

3 іншого боку, здатність $2^{\prime}-5^{\prime}-\mathrm{A}_{3}$ впливати на скорочення гладеньких м'язів можна пояснити тим, що 2'-5'- A $_{3}$ може безпосередньо активувати цАМФ-залежну протеїнкіназу, яка, у свою чергу, впливала б на вивільнення $\mathrm{Ca}^{2+} 3$ ріанодин-чутливого депо саркоплазматичного ретикулума. У зв’язку з цим нами досліджено вплив $2^{\prime}-5^{\prime}-\mathrm{A}_{3}$ на активність ряду кіназ. Головним об'єктом дослідження була не вивчена до цього часу взаємодія $2^{\prime}-5^{\prime}-\mathrm{A}_{3}$ з S100A1.

Матеріали та методи. Комп'ютерне моделювання взаємодї білка $S 100 A 1$ з 2'-5'- $A_{3}$. Для підготовки молекули ліганду (у нашому випадку це молекула олігоаденілату) використовували програму AutoDockTools (ADT), доступну на сайті розробників http://mgltools. scripps.edu/downloads. Молекулу дефосфорильованого 2'-5' - А було згенеровано в програмі ChemDoodle3D, доступній за посиланням https://www.chemdoodle.com/features/3d/. Молекулу ліганду завантажували в ADT, де іiі програмно редагували шляхом додавання атомів водню та деяких інших операцій, після чого молекулу ліганду зберігали у форматі PDBQT.

Подібну процедуру проведено для 3D структури S100A1, яку було завантажено з вебcайта www.rcsb.org (2LP3) та відкрито в ADT. До молекули рецептора додавали атоми водню, заряди, визначали заряди в одиницях, що використовуються програмою, типи атомів.

Для докінгу використовували метод "Single docking experiment with AutoDock Vina", який є базовим для докінгу одиничної молекули ліганду в структуру рецептора. Для візуалізації результатів докінгу застосовували програму РуMol.

Метод ядерно-магнітного резонансу. Для запису ЯМР спектрів використовували спектрометр Unity 500 ("Varian”, США), який характеризується значенням ${ }^{1} \mathrm{H}$ резонансної частоти 500,606 мГц. Прилад було обладнано трьома каналами, z-градієнтною приставкою та потрійною вимірювальною головкою, здатною фіксувати значення резонансів ізотопів ${ }^{1} \mathrm{H} /{ }^{13} \mathrm{C} /{ }^{15} \mathrm{~N}$ з можливістю зворотної детекції.

Зразки для ЯМР готували шляхом розчинення 0,3 мM ${ }^{15} \mathrm{~N}$-міченого білка S100A1 людини в буфері, що містив $\mathrm{H}_{2} \mathrm{O} / \mathrm{D}_{2} \mathrm{O}$ (90\%/10\%), 20 мM Tris-d11 та 150 мM NaCl. Усi спектри було записано при $25^{\circ} \mathrm{C}$, а як зовнішній непрямий контроль використано розчин натрій-2,2,-диметил-2-силапентан-5-сульфонат (DSS) 3 коефіцієнтами $\Xi=0,251449530$ та $\Xi=0,101329118$ для резонансних частот ${ }^{13} \mathrm{C}$ та ${ }^{15} \mathrm{~N}$ відповідно $(z)$. Для того щоб отримати дані про взаємодію апо-S100A1 та 2'-5'- A $_{3}$, розчин білка титрували концентрованим 130 мкМ розчином 2'-5'- A $_{3}$, приготованим у тому самому буфері. Білковий зразок титрували шляхом послідовного додавання невеликих об'ємів (10 мкл) олігоаденілату. Після кожного додавання титранту записували двовимірний ${ }^{1} \mathrm{H}^{15}{ }^{15} \mathrm{HSQC}$ спектр. Для обробки даних ЯМР спектроскопії користувалися програмою NMR Pipe.

Результати та їх обговорення. Вивчення впливу 2'-5'- $A_{3}$ на структуру $5100 A 1$ методом ядерно-магнітного резонансу. У результаті аналізу отриманих ${ }^{1} \mathrm{H}$ та ${ }^{15} \mathrm{~N}$ HSQC ЯМР груп даних виявлено ряд амінокислотних залишків з більшими відносно інших значеннями хімічних зсувів амідних груп (рис. 1). 


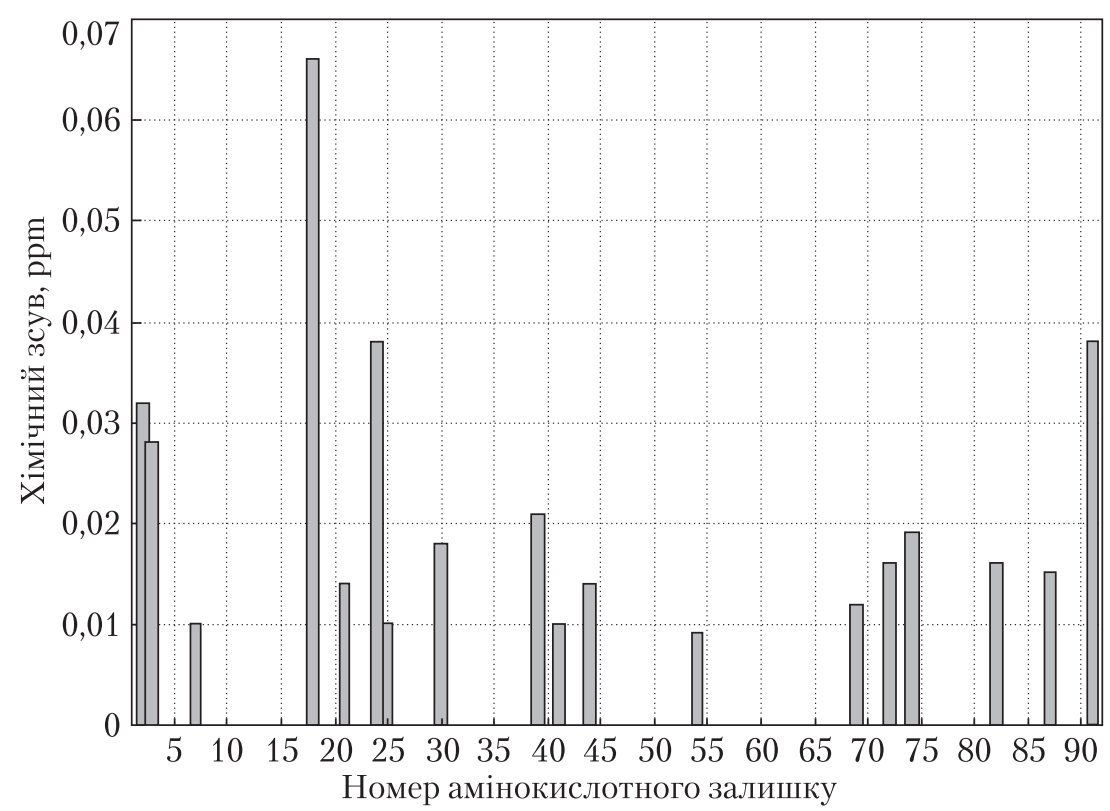

Puc. 1. Діаграма залежності значення хімічного зсуву від номера амінокислотного залишку за умов титрування S100A1 розчином 2'-5'- $\mathrm{A}_{3}$. Наведено лише амінокислотні залишки з високими значеннями величин хімічних зсувів

Встановлено, що амінокислотні залишки з найбільшими значеннями хімічних зсувів знаходяться в межах $\mathrm{Ca}^{2+}$-зв'язувальних петель - центральних частин EF-hand доменів. Більшість сигналів надходила від $\mathrm{N}$-кінцевого регіону $\mathrm{Ca}^{2+}$-зв'язувального мотиву, який містить такі амінокислотні залишки: Гіс18, Ліз21, Асп24, Ліз25 та Ліз30, що характеризуються сильною залежністю від умов проведення експерименту, а саме температури, $\mathrm{pH}$ та/або іонної сили розчину.

Значення хімічних зсувів амінокислотних залишків, Вал69 та Глн72 у межах С-кінцевого домену білка S100A1 у результаті зв'язування з 2'-5'- $\mathrm{A}_{3}$ виявилися значно нижчими.

Важливо зазначити, що Фен44 разом із Лей 45 та Ліз49 формують петельний домен глобули S100A1, котрий, як і лінкерний домен, відіграє важливу роль у білок-пептидних взаємодіях S100A1 з цільовими білками.

У результаті експериментів також вдалося зафіксувати хімічні зсуви амінокислотних залишків у межах міжмономерного інтерфейсу глобули S100A1 у разі взаємодії з 2'-5'- $\mathrm{A}_{3}-$ Сер2, Глу3, Ала7, Тир74, Тре82, Асн87 та Глу91. Ці амінокислотні залишки залучені у формування гідрофобних міжмономерних контактів між спіралями I/I' та IV/IV' у межах гомодимеру S100A1 (рис. 2).

Комп'ютерне моделювання взаємодіi $S 100 A 1$ з 2'-5'- $A_{3}$. 3 метою визначення амінокислотних залишків білка S100A1, які взаємодіють з 2'-5'- $\mathrm{A}_{3}$ шляхом утворення водневих або електростатичних зв'язків (рис. 3), було застосовано метод комп'ютерного моделювання. Отримані дані є важливим додатком до результатів, одержаних раніше методом ЯМР, на основі яких нами було висунуто припущення, що 2'-5'- $\mathrm{A}_{3}$ може взаємодіяти 3 міжмономерним інтерфейсом S100A1. Виявилося, що залишок Асн87, який локалізований саме в міжмономерному інтерфейсі, знаходиться в радіусі $5 \AA$ від місця зв'язування 2'-5'- $\mathrm{A}_{3} \mathrm{i}$, най- 

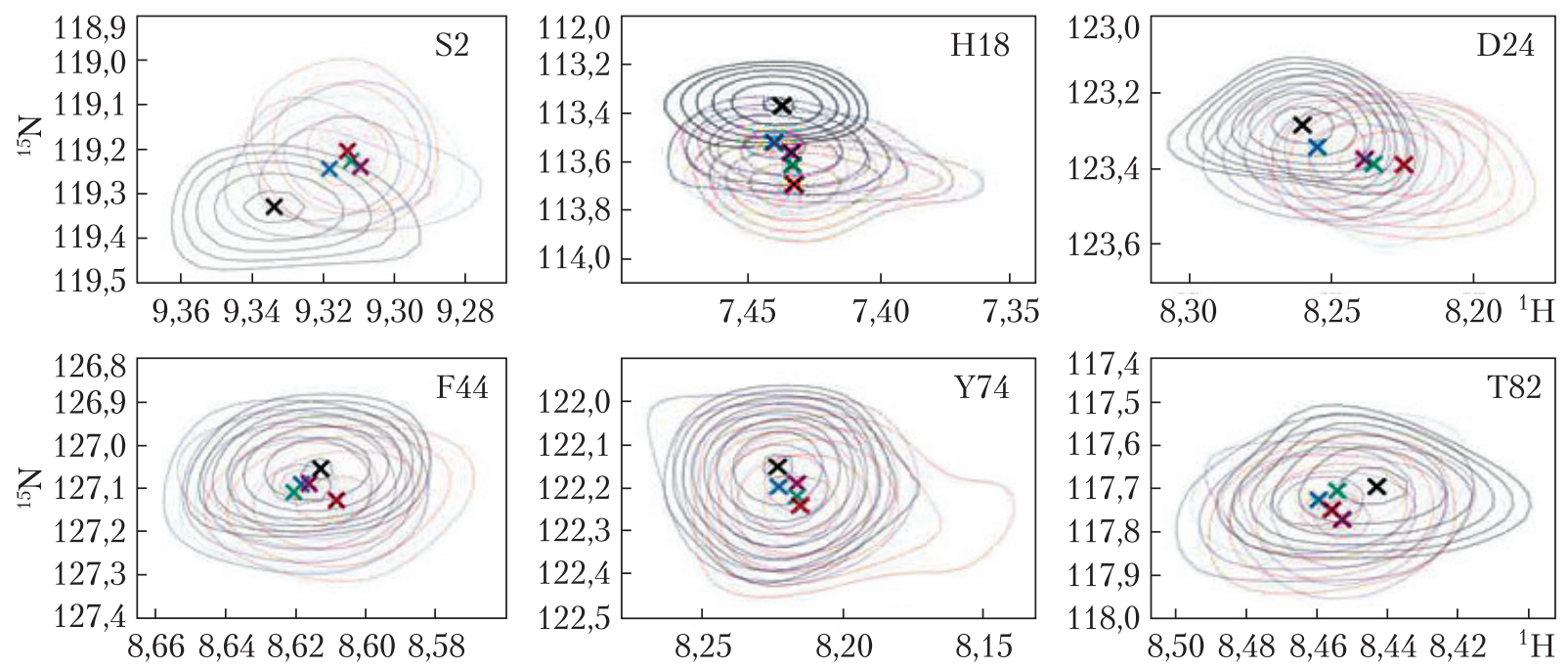

Puc. 2. Значення хімічних зсувів, отримані в ході двовимірного $2 \mathrm{D}^{1} \mathrm{H}^{-15} \mathrm{~N} H \mathrm{HQC}$ експерименту, для двоміченого ${ }^{13} \mathrm{C},{ }^{15} \mathrm{~N}$-апо-S100A1 людини для деяких амінокислотних залишків у випадку додавання 10 мкл 130 мМ розчину $2^{\prime}-5^{\prime}-\mathrm{A} 3$

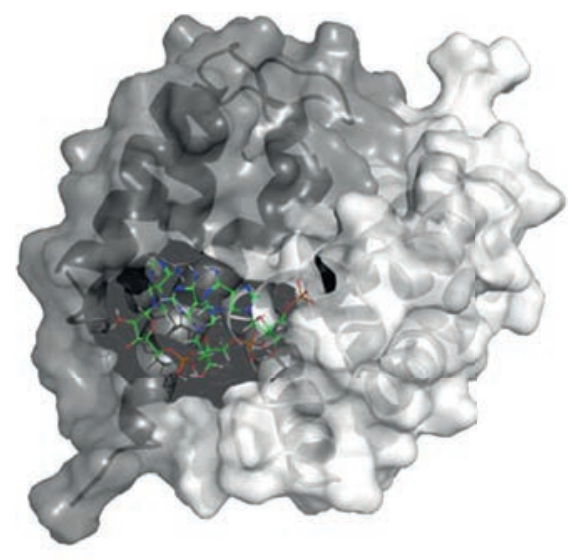

Puc. 3. Комплекс S100A1 з 2'-5'-A , візуалізований у програмі PyMOL, поверхневе забраження білкової глобули з паличковою моделлю $2^{\prime}-5^{\prime}-\mathrm{A}_{3}$

імовірніше, безпосередньо взаємодіє з ним (див. рис. 3). Інші амінокислотні залишки міжмономерного інтерфейсу, що характеризувалися значними хімічними зсувами в ЯМР експериментах (Вал54, Тир74, Тре82), знаходяться далі від місця зв'язування $2^{\prime}-5^{\prime}-\mathrm{A}_{3}-$ в радіусі $6-7 \AA$ і і не взаємодіють безпосередньо з $2^{\prime}-5^{\prime}-\mathrm{A}_{3}$.

Показано, що залишок Вал69, який локалізується в межах $\mathrm{C}$-кінцевого домену $\mathrm{Ca}^{2+}$-зв'язувального домену білка S100A1, безпосередньо взаємодіє з 2'-ОН-групою рибози III залишку АМФ. Важливо, що Вал69 характеризується нижчим, ніж для Глу91 ще одного амінокислотного залишку С-кінцевого домену $\mathrm{Ca}^{2+}$-зв’язувального домену білка S100A1, значенням хімічного зсуву.

На відміну від результатів ЯМР спектроскопії, які вказують на значні хімічні зсуви амінокислотних залишків С-кінцевого фрагмента альфа-спіралі IV (Глу39, Лей41, Фен44, Глу91), дані, одержані методом комп’ютерного моделювання, не підтверджують виникнення взаємодії 2'-5'-А 3 цими амінокислотними залишками. Проте залишок Фен44 знаходиться недалеко (6-7 А) від місця зв'язування з 2'-5'-A i, можливо, “реагує” на його зв'язування з іншими амінокислотними залишками та конформаційними змінами, що виникають у результаті цієї події.

Результати експерименту свідчать про те, що 2'-5'- A $_{3}$ утворює три зв’язки з амінокислотними залишками в радіусі $5 \AA$ А. Один 3 них - водневий - утворюється між $\mathrm{NH}_{2}$-групою залишку аденіну I залишку АМФ та СО-групою Ала80. Другий та третій зв'язки - електро- 
статичні. Вони утворюються між $\mathrm{PO}_{2}$-групою II залишку АМФ і СО-групою Вал69 та між $\mathrm{PO}_{2}$-групою III залишку АМФ і СО-групою Асн64.

Нами виявлено хімічні зсуви амінокислотних залишків у структурно та функціонально важливих ділянках білка S100A1, серед яких N-кінцевий $\mathrm{Ca}^{2+}$-зв'язувальний домен, С-кінцевий $\mathrm{Ca}^{2+}$-зв'язувальний домен, альфа-спіраль IV та міжмономерний інтерфейс, на підставі чого зроблено припущення щодо амінокислотних залишків, з якими безпосередньо

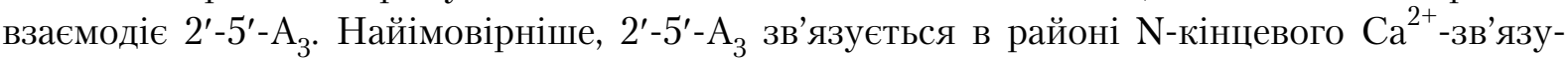
вального домену та лінкерного регіону. Важливо зауважити, що через невисокі значення доступності перерахованих вище амінокислотних залишків до взаємодії з розчинником,

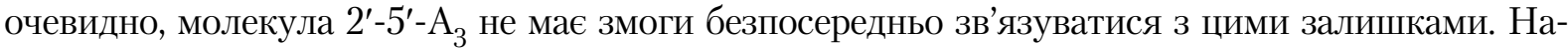
багато вірогіднішим є сценарій, за якого молекула олігоаденілату приєднується до S100A1 в іншому місці (найімовірніше, в районі $\mathrm{Ca}^{2+}$-зв'язувального домену та/або лінкерного регіону), а конфірмаційні зміни, зумовлені його приєднанням, передаються на чутливий до подібних змін міжмономерний інтерфейс.

Методом комп’ютерного моделювання зв'язування 2'-5'- $\mathrm{A}_{3}$ з S100A1 вдалося частково підтвердити отримані раніше результати ЯМР стосовно електростатичної взаємодії $\mathrm{PO}_{2}$ групи II залишку АМФ та СО-групи Вал69, що може пояснювати значний хімічний зсув аміноксилотного залишку. Вал69 є частиною С-кінцевого домену $\mathrm{Ca}^{2+}$-зв'язувального домену білка S100A1. Очевидно, не варто стверджувати, що утворення трьох вищеописаних міжмолекулярних зв'язків може свідчити про наявність специфічного до 2'-5'- $\mathrm{A}_{3}$ сайта зв’язування на поверхні S100A1. Більш вірогідно, що взаємодія S100A1-2'-5'- , $_{3}$ неспецифічна, доказом чого є значення константи зв'язування $-2 \cdot 10^{4} \mathrm{M}^{-1}$.

Таким чином, нами частково підтверджено той факт, що $\mathrm{PO}_{2}$-група II залишку АМФ і СО-група Вал69 взаємодіють електростатично, внаслідок чого відбувається значний хімічний зсув амінокислотного залишку. Вал69 є частиною С-кінцевого домену $\mathrm{Ca}^{2+}$-зв'язувального домену білка S100A1, зв’язування ліганду з яким теоретично може неістотно змінювати профіль зв'язування $\mathrm{Ca}^{2+}$, ледве помітні зміни якого нам вдалося зафіксувати раніше [5].

\section{ЦИТОВАНА ЛІТЕРАТУРА}

1. Pauwels R. Mode of action of corticosteroids in asthma and rhinitis. Clin. Allergy. 1986. 16. P. 281-288. https://doi.org/10.1111/j.1365-2222.1986.tb01959

2. Філіппов І.Б., Ткачук З.Ю., Дубей І.Я. Механізми регуляції судинного тонусу 2 '-5'-олігоаденілатами. Допов. Наи. акад. наук Укр. 2010. № 6. С. 152-157.

3. Tkachuk Z.Yu., Dubey I.Ya., Tkachuk L.V., Dubey L.V., Shlykov S.G., Babich L.G. The effect of 2'-5'-oligoadenylates on calcium binding to Calmodulin. $\mathrm{Ca}^{2+}$-Binding Proteins and $\mathrm{Ca}^{2+}$ Function in Health and Disease: Proceedings of the17th Int. symp. (Beijing, 10-21 July 2011). Beijing, China, 2011.

4. Wright N.T., Prosser B.L., Varney K.M., Zimmer D.B., Schneider M.F., Weber D.J. S100A1 and calmodulin compete for the same binding site on ryanodine receptor.J. Biol. Chem. 2008. 283. P. 6676-26683. https://doi. org/10.1074/jbc.M804432200

5. Skorobogatov O.Yu., Lozhko D.N., Zhukov I.Yu., Kozlov O.V., Tkachuk Z.Yu. Study of dephosphorylated $2^{\prime}-5$ '-linked oligoadenylates impact on apo-S100A1 protein conformation by heteronuclear NMR and circular dichroism. Biopolym. Cell. 2014. 30. P. 279-285. https://doi.org/10.7124/bc.0008A1

Надійшло до редакції 30.08.2019 


\section{REFERENCES}

1. Pauwels, R. (1986). Mode of action of corticosteroids in asthma and rhinitis. Clin. Allergy, 16, pp. 281-288. https://doi.org/10.1111/j.1365-2222.1986.tb01959

2. Filippov, I. B., Tkachuk, Z. Yu. \& Dubei, I. Ya. (2010). Mechanisms of vessel tone regulation by 2'-5'oligoadenylates. Dopov. Nac. akad. nauk Ukr., No. 6, pp. 152-157 (in Ukrainian).

3. Tkachuk, Z. Yu., Dubey, I. Ya., Tkachuk, L. V., Dubey, L. V., Shlykov, S. G. \& Babich, L. G. (2011, July). The effect of 2'-5'-oligoadenylates on calcium binding to Calmodulin. Proceedings of the 17th International Symposium on $\mathrm{Ca}^{2+}$-Binding Proteins and $\mathrm{Ca}^{2+}$ Function in Health and Disease, Beijing, China.

4. Wright, N. T., Prosser, B. L., Varney, K. M., Zimmer, D. B., Schneider, M. F. \& Weber, D. J. (2008). S100A1 and calmodulin compete for the same binding site on ryanodine receptor. J. Biol. Chem., 283, pp. 26676-26683. https://doi.org/10.1074/jbc.M804432200

5. Skorobogatov, O. Yu., Lozhko, D. N., Zhukov, I. Yu., Kozlov, O. V. \& Tkachuk, Z. Yu. (2014). Study of dephosphorylated 2'-5'-linked oligoadenylates impact on apo-S100A1 protein conformation by heteronuclear NMR and circular dichroism. Biopolym. Cell., 30, pp. 279-285. https://doi.org/10.7124/bc.0008A1

Received 30.08.2019

\section{А.Ю. Скоробогатов, И.Ю. Жуков, З.Ю. Ткачук}

Институт молекулярной биологии и генетики НАН Украины, Киев

E-mail: skorobogatov.alx@gmail.com

\section{СТРУКТУРНЫЕ МЕХАНИЗМЫ ВЗАИМОДЕЙСТВИЯ}

ДЕФОСФОРИЛИРОВАННЫХ 2'-5'-ТРИАДЕНИЛАТОВ С БЕЛКОМ S100А1

С помощью методов ЯМР спектроскопии и компьютерного моделирования изучали структурные механизмы взаимодействия дефосфорилированного 2'-5'-триаденилата с белком S100A1. Установлено, что дефосфорилированный 2'-5'-триаденилат связывается с белком S100A1 на грани $\mathrm{Ca}^{2+}$-связывающего домена и линкерного региона. Образование комплекса белок-триаденилат стабилизируется тремя связями, два из которых электростатические, а один - водородный. Зафиксированные особенности взаимодействия дефосфорилированного 2'-5'-триаденилата с S100A1 могут служить в качестве основы для объяснения одной из неописанных ранее функций дефосфорилированного 2'-5'-триаденилата.

Ключевые слова: дефосфорилированные 2'-5'-триаденилаты, белок S100A1, компьютерное моделирование, ЯМР.

\section{O.Yu. Skorobogatov, I.Yu. Zhukov, Z.Yu. Tkachuk}

Institute of Molecular Biology and Genetics of the NAS of Ukraine, Kyiv

E-mail: skorobogatov.alx@gmail.com

\section{STRUCTURAL MECHANISMS OF INTERACTION}

OF TRIPHOSPHORYLATED 2'-5'-TRIADENYLATES WITH S100A1 PROTEIN

We study the structural mechanisms of interaction of dephosphorylated $2^{\prime}-5^{\prime}$-triadenylates with S100A1 protein by NMR spectroscopy and computer simulation methods. Earlier, it was demonstrated that $2^{\prime}-5^{\prime}$-triadenylates are capable of stimulating the muscle contraction via a direct or indirect interaction with the Ryanodine receptor (RyR). One of the key regulators of this intracellular $\mathrm{Ca}^{2+}$ pump is a calcium-binding protein S100A1. We assumed that the naturally occurring $2^{\prime}-5^{\prime}$-triadenylate may interact with S100A1 directly, by exhibiting its effect, and took a detailed look at the interaction. It is shown that dephosphorylated $2^{\prime}-5^{\prime}$-triadenylate binds to S100A1 within the $\mathrm{Ca}^{2+}$-binding loop/linker interface, where the aminoacids within the S100A1 homodimer displayed the highest amplitude of chemical shifts. Complex formation turned out to be stabilized by the formation of two electrostatic and one hydrogen bonds. The data obtained may suggest an insight into how the naturally occurring $22^{\prime}-5^{\prime}$-triadenylate exhibits its purely biological function. An alternative possible scenario is the interaction between $2^{\prime}-5^{\prime}$-triadenylate and CAM kinase, which leads to the alteration of the latter's functioning, which further affects the RyR. S100A1's antagonist regarding the RyR functioning, Calmodulin, was earlier shown to interact with $2^{\prime}-5^{\prime}$-triadenylate, which led to the $\mathrm{Ca}^{2+}$ affinity alteration of the latter. Collectively, these data assume that $2^{\prime}-5^{\prime}$-triadenylate interacts with both major regulators of RyR's $\mathrm{Ca}^{2+}$-releasing activity.

Keywords: dephosphorylated 2'-5'-triadenylates, S100A1 protein, computer simulation, NMR. 